\title{
Dividend Policy : Dipengaruhi oleh Leverage, Likuiditas, Profitabilitas dan Ukuran Perusahaan pada Perusahaan Foods and Beverages yang Terdaftar di Bursa Efek Indonesia Periode 2013-2017
}

\author{
Tatas Ridho Nugroho ${ }^{1}$, Muhammad Bahril Ilmiddaviq ${ }^{2}$ \\ Fakultas Ekonomi, Universitas Islam Majapahit ${ }^{1,2}$ \\ tatasridho@unim.ac.id
}

\begin{abstract}
Abstrak
Kebijakan dividen adalah kebijakan dalam pembagian keuntungan perusahaan dengan nama dan dalam bentuk apapun namun dalam prakteknya sering dijumpai pembagian atau pembayaran dividen secara terselubung. Dividen dibagikan dalam interval waktu yang tetap yaitu setiap setengah tahun atau satu tahun. Penelitian ini bertujuan untuk mengetahui tentang pengaruh leverage, likuiditas, profitabilitas dan ukuran perusahaan terhadap kebijakan dividen. Penelitian ini menggunakan pendekatan kuantitatif dengan metode analisis regresi linier berganda. Populasi dalam penelitian ini adalah perusahaan manufaktur yang terdaftar di Bursa Efek Indonesia (BEI), lebih utamanya perusahaan foods and beverages pada periode 2013-2017. Sampel yang dikumpulkan menggunakan metode purposive sampling. Hasil penelitian uji koefisien determinasi sebesar 34,7\% menandakan kemampuan variabel independen dalam menjelaskan variabel dependen, sementara 65,3\% dijelaskan oleh variabel lain. Hasil uji simultan menunjukkan bahwa variabel independen bersama-sama mempengaruhi variabel dependen dan hasil uji parsial menunjukkan bahwa leverage berpengaruh signifikan negatif, likuiditas tidak berpengaruh signifikan, profitabilitas berpengaruh signifikan positif dan ukuran perusahaan tidak berpengaruh signifikan terhadap kebijakan dividen.
\end{abstract}

Kata Kunci : Leverage, Likuiditas, Profitabilitas, Kebijakan Dividen

\begin{abstract}
Dividend policy is a policy in dividing profit of company that can be with name and everything, but in it practices often encountered dividing or paying it by unseen. Dividing dividend in appropriate time intervals that is every half year or in a year. This study aims to knows about the influence of Leverage, Liquidity, Profitability and Size towards Dividend Policy. This study using a quantitative approach with using a multiple linear regression analysis method. The population in this study is registered companies in stock exchange of Indonesia, food and beverages year 2013-2017 is the main focus of this study. The sample of this study is collected by purposive sampling method. The result of coefficient determination test that $34,7 \%$ is showing the ability of independen variable determine dependen variable, temporary $65,3 \%$ determine by other variables. The simultan test showed that independen variable together influence dependen variable and the parsial test showed how does leverage has an negative significant impact towards dividend policy, liquidity hasn't a significant impact towards dividend policy, profitability has a positive impact towards dividend policy and size hasn't a significant impact towards dividend policy.
\end{abstract}

Keywords : Leverage, Liquidity, Profitability, Size, Dividend Policy 


\section{PENDAHULUAN}

Pada era globalisasi saat ini kemajuan ilmu pengetahuan dan teknologi menyebabkan kegiatan perekonomian dunia mengalami perkembangan yang pesat. Aktivitas pasar modal merupakan salah satu contoh adanya kemajuan dalam bidang ilmu pengetahuan dan teknologi yang lebih modern dalam perkembangan ekonomi pada umumnya. Pasar modal dianggap sebagai media yang sangat efektif untuk dapat menyalurkan dan menginvestasikan dana yang berdampak produktif, diartikan bahwa dana tersebut digunakan dan dikelola dengan baik sehingga menguntungkan bagi investor. Melalui kegiatan di pasar modal, perusahaan dapat memperoleh dana untuk membiayai operasional dan perluasan perusahaan.

Perusahaan manufaktur adalah salah satu dari banyaknya perusahaan yang terdaftar dalam pasar modal. Pertumbuhan ekonomi di Indonesia didukung oleh berbagai sektor. Masyarakat diharapkan mampu ikut serta dalam menggerakkan perekonomian Indonesia, salah satunya melakukan kegiatan pasar modal. Pasar modal menggambarkan keadaan ekonomi suatu negara. Semakin maju dan berkembang pasar modal suatu negara, maka semakin maju dan berkembang pula perekonomian negara tersebut. Banyak alternatif yang dapat dipilih untuk berinvestasi di pasar modal, salah satunya adalah dengan melakukan pembelian saham-saham karena berpotensi memiliki keuntungan dalam pembagian dividen atas laba yang dihasikan perusahaan sesuai dengan saham yang dimilki dan atas kenaikan harga saham.

Indonesia merupakan satu dari beberapa negara, dimana pasar modalnya memiliki peranan penting dalam memobilisasi dana dari investor yang ingin berinvestasi di pasar modal. Berinvestasi merupakan aktivitas yang dihadapkan pada berbagai macam risiko dan ketidakpastian oleh para investor. Untuk mengurangi kemungkinan risiko dan ketidakpastian tersebut, seorang investor memerlukan berbagai macam informasi lain yang relevan seperti kondisi ekonomi dan politik negara. Karena hal utama yang diharapkan dari berinvestasi adalah adanya keuntungan yang akan diperoleh di masa mendatang.

Pembayaran dividen merupakan salah satu cara untuk mengembalikan keuntungan perusahaan kepada pemegang saham. Besarnya nilai dividen yang akan diterima pemegang saham sangat bergantung pada kebijakan dividen yang bersangkutan. Kebijakan dividen merupakan keputusan apakah keuntungan atau laba yang diperoleh perusahaan pada akhir tahun akan dibagi dalam bentuk dividen kepada pemegang saham atau laba akan ditahan untuk pembiayaan investasi di masa yang akan datang. Kebijakan pembayaran dividen mempunyai pengaruh bagi pemegang saham dan perusahaan yang membayar dividen, mereka umumnya menginginkan pembagian dividen yang relatif stabil karena hal tersebut akan mengurangi ketidakpastian hasil dari investasi yang mereka lakukan dan dapat meningkatkan kepercayaan pemegang saham terhadap perusahaan sehingga dengan begitu nilai saham pun akan meningkat.

Menurut Jama'an dalam Midiastuty, Pranata P, dkk (2013:157) signalling theory mengemukakan tentang bagaimana seharusnya sebuah perusahaan memberikan sinyal kepada pengguna laporan keuangan. Teori Keagenan (Agency Theory), teori ini mengasumsikan bahwa manajemen mempunyai informasi yang lebih lengkap dan akurat dibandingkan pihak luar perusahaan (investor) mengenai faktor-faktor yang mempengaruhi nilai perusahaan. "Rasio keuangan adalah angka yang diperoleh dari hasil perbandingan satu pos laporan keuangan dengan pos lainnya yang mempunyai hubungan yang relevan dan signifikan (berarti)" (Harahap, 2011:297). Menurut Kamus Besar Bahasa Indonesia (KBBI), dividen adalah bagian laba atau pendapatan yang besarnya ditetapkan oleh direksi serta disahkan oleh rapat pemegang saham untuk dibagikan kepada para pemegang saham. Menurut Kasmir (2014:112-113) leverage menunjukkan sejauh mana aktiva perusahaan 
dibiayai dengan utang dan leverage ratio merupakan rasio yang digunakan untuk mengukur sejauh mana aktiva perusahaan dibiayai dengan utang.

Menurut Kamus Besar Bahasa Indonesia (KBBI), likuiditas adalah posisi uang ataupun kas suatu perusahaan dan kemampuannya untuk memenuhi kewajiban yang jatuh tempo tepat pada waktunya, kemampuan untuk memenuhi kewajiban membayar hutang tepat waktu. Profitabilitas adalah kemampuan menghasilkan laba selama periode tertentu dengan menggunakan aktiva atau modal, baik modal secara keseluruhan maupun modal sendiri (Barus dan Leliani, 2013:74). Menurut Niresh (2014:57) ukuran perusahaan adalah faktor utama untuk menentukan profitabilitas dari suatu perusahaan dengan konsep besar karena dapat menghasilkan produk dengan harga per unit yang rendah. Perusahaan dengan ukuran besar membeli bahan baku (input produksi) dalam jumlah yang besar sehingga perusahaan akan mendapat potongan harga (quantity discount) lebih banyak dari pemasok.

\section{METODE PENELITIAN}

Jenis pendekatan yang dipilih dalam penelitian ini adalah penelitian penjelasan dengan menggunakan pendekatan kuantitatif, karena dapat memberikan informasi yang luas dari suatu populasi dan data yang akurat secara empiris serta dapat diukur. Bahan dan alat utama dalam penelitian ini adalah dokumen laporan keuangan yang alat utamanya berupa daftar list nama perusahaan manufaktur terdaftar di Bursa Efek Indonesia. Data penelitian yang berupa dokumen laporan keuangan diambil dengan mendatangi kantor cabang Bursa Efek Indonesia (BEI) yang berada di Surabaya. Penelitian ini dilakukan pada perusahaan manufaktur foods and beverages yang terdaftar di Bursa Efek Indonesia periode 2013-2017 yang melaporkan laporan keuangnnya sejumlah 17 perusahaan dan sebanyak 8 perusahaan profitable menjadi sampel akhir penelitian.

Teknik pengumpulan data penelitian menggunkana teknik purposive sampling merupakan salah satu teknik pengambilan sampel non probabilitas, dimana teknik pemilihan secara tidak acak yang informasinya diperoleh berdasarkan pertimbangan tertentu dan umumnya disesuaikan dengan tujuan atau masalah penelitian. Leverage sebagai variabel $\mathrm{X}_{1}$ menggunakan Debt to Equity Ratio untuk menilai total hutang dengan total ekuitas (total modal). Likuiditas sebagai variabel $\mathrm{X}_{2}$ menggunakan Current Ratio dimana rasio ini digunakan untuk menilai aset lancar dan kewajiban lancar. Profitabilitas sebagai variabel $\mathrm{X}_{3}$ menggunakan Return On Equity dimana rasio ini digunakan untuk mengukur kemampuan perusahaan memperoleh laba dalam hubungan dengan penjualan, total aktiva maupun modal itu sendiri. Ukuran perusahaan atau Size merupakan rasio yang menunjukkan seberapa banyak aset yang dimiliki oleh perusahaan. Kebijakan Dividen sebagai variabel terikat menggunakan Dividend Payout Ratio dengan menghitung dividen saham dengan sebagian dari laba bersih perusahaan yang dibagikan kepada para pemegang saham.

Peneliti menggunakan bantuan program Statistical Package for the Social Science (SPSS) 19.00 untuk mengolah data dan menarik kesimpulan dari suatu penelitian. Teknik analisis data yang digunakan adalah analisis perhitungan rasio; analisis statistik deskriptif; analisis statistik inferensial yang terdiri dari uji asumsi klasik seperti uji normalitas, uji multikolinearitas, uji autokorelasi, uji heteroskedastisitas dan uji regresi linear berganda yang terdiri dari uji statistik $\mathrm{t}$, uji statistik $\mathrm{F}$ dan uji koefisien determinasi $\left(\mathrm{R}^{2}\right)$. 


\section{HASIL DAN PEMBAHASAN}

Tabel 1 : Perhitungan Debt Equity Ratio

\begin{tabular}{lcccccc}
\hline $\begin{array}{c}\text { Kode } \\
\text { Emiten } \\
\text { Perusahaan }\end{array}$ & $\begin{array}{c}\mathbf{2 0 1 3} \\
(\mathbf{\%})\end{array}$ & $\begin{array}{c}\mathbf{2 0 1 4} \\
\mathbf{( \% )}\end{array}$ & $\begin{array}{c}\text { Tahun } \\
\mathbf{2 0 1 5} \\
(\mathbf{\%})\end{array}$ & $\begin{array}{c}\mathbf{2 0 1 6} \\
(\boldsymbol{\%})\end{array}$ & $\begin{array}{c}\mathbf{2 0 1 7} \\
(\boldsymbol{\%})\end{array}$ & Rata-rata \\
\hline AISA & 1,13 & 1,05 & 1,28 & 1,17 & 1,18 & 1,16 \\
DLTA & 0,28 & 0,3 & 0,22 & 0,18 & 0,19 & 0,23 \\
ICBP & 0,6 & 0,66 & 0,62 & 0,56 & 0,56 & 0,6 \\
MLBI & 0,8 & 3,03 & 1,74 & 1,77 & 1,59 & 1,79 \\
MYOR & 1,47 & 1,51 & 1,18 & 1,06 & 1,06 & 1,26 \\
ROTI & 1,32 & 1,23 & 1,28 & 1,02 & 1,03 & 1,18 \\
SKBM & 1,47 & 1,04 & 1,22 & 1,72 & 0,52 & 1,19 \\
STTP & 1,12 & 1,08 & 0,9 & 1 & 0,73 & 0,97 \\
Maksimum & 1,47 & 3,03 & 1,74 & 1 & 1,59 & \\
Minimum & 0,6 & 0,3 & 0,22 & 0,18 & 0,19 & \\
Rata-rata & 1,28 & 1,24 & 1,05 & 1,06 & 0,86 & \\
Growth & & 0,01 & $-0,01$ & 0 & $-0,04$ & \\
\hline Sumber $:$ & & & & & & \\
\hline
\end{tabular}

Sumber : data diolah, 2018

Tabel 1 menggambarkan bahwa Debt Equity Ratio tahun 2013-2017 mempunyai rata-rata setiap tahunnya masing-masing sebesar 1,28\%,1,24\%,1,05\%,1,06\% dan 0,86\% dengan nilai maksimum $1,74 \%$ didapat oleh perusahaan MLBI, sedangkan untuk nilai minimum sebesar $0,6 \%$ didapat oleh DLTA. Dari tahun 2013-2017, tingkat pertumbuhan (growth) menurun.

Tabel 2. Perhitungan Current Ratio

\begin{tabular}{|c|c|c|c|c|c|c|}
\hline $\begin{array}{c}\text { Kode Emiten } \\
\text { Perusahaan }\end{array}$ & $\begin{array}{c}2013 \\
(\%)\end{array}$ & $\begin{array}{l}2014 \\
(\%)\end{array}$ & $\begin{array}{l}\text { Tahun } \\
2015 \\
(\%)\end{array}$ & $\begin{array}{l}2016 \\
(\%)\end{array}$ & $\begin{array}{l}2017 \\
(\%)\end{array}$ & Rata-rata \\
\hline AISA & 175,03 & 266,33 & 162,29 & 237,56 & 162,24 & 200,69 \\
\hline DLTA & 470,54 & 447,32 & 642,37 & 760,39 & 778,3 & 619,784 \\
\hline ICBP & 241,06 & 218,32 & 232,6 & 240,68 & 220,46 & 230,624 \\
\hline MLBI & 97,75 & 51,39 & 58,42 & 67,95 & 81,24 & 71,35 \\
\hline MYOR & 244,34 & 208,99 & 236,53 & 225,02 & 225,97 & 228,17 \\
\hline ROTI & 113,64 & 136,64 & 205,34 & 296,23 & 101,99 & 170,768 \\
\hline SKBM & 124,83 & 147,71 & 114,51 & 110,72 & 170,25 & 133,604 \\
\hline STTP & 114,24 & 148,42 & 157,89 & 165,45 & 217,08 & 160,616 \\
\hline Maksimum & 470,54 & 447,32 & 642,37 & 760,39 & 778,3 & \\
\hline Minimum & 97,75 & 51,39 & 58,42 & 67,95 & 81,24 & \\
\hline Rata-rata & 197,68 & 203,14 & 226,24 & 263 & 244,69 & \\
\hline Growth & & 1,04 & 1,06 & 1,07 & 1,16 & \\
\hline
\end{tabular}

Sumber : data diolah, 2018

Tabel 2 menggambarkan bahwa Current Ratio tahun 2013-2017 mempunyai rata-rata setiap tahunnya masing-masing sebesar $197,68 \%, 203,14 \%, 226,24 \%, 263 \%$ dan $244,69 \%$ dengan nilai maksimum 778,3\% didapat oleh perusahaan DLTA, sedangkan untuk nilai minimum sebesar 0,6\% didapat oleh MLBI. Dari tahun 2013-2017, tingkat pertumbuhan (growth) mengalami kenaikan. 
Tabel 3. Perhitungan Return On Equity

\begin{tabular}{lcccccc}
\hline $\begin{array}{l}\text { Kode Emiten } \\
\text { Perusahaan }\end{array}$ & $\begin{array}{c}\mathbf{2 0 1 3} \\
(\boldsymbol{\%})\end{array}$ & $\begin{array}{c}\mathbf{2 0 1 4} \\
(\mathbf{\%})\end{array}$ & $\begin{array}{c}\text { Tahun } \\
\mathbf{2 0 1 5}\end{array}$ & $\begin{array}{c}\mathbf{2 0 1 6} \\
(\boldsymbol{\%})\end{array}$ & $\begin{array}{c}\mathbf{2 0 1 7} \\
(\boldsymbol{\%})\end{array}$ & Rata-rata \\
\hline AISA & 14,71 & 10,52 & 9,42 & 16,87 & 3,98 & 11,1 \\
DLTA & 39,98 & 37,68 & 22,6 & 25,14 & 18,01 & 28,68 \\
ICBP & 16,85 & 16,83 & 17,84 & 19,63 & 15,34 & 17,30 \\
MLBI & 118,6 & 143,53 & 64,83 & 119,68 & 96,08 & 108,54 \\
MYOR & 26,87 & 24,07 & 24,07 & 22,16 & 14,12 & 22,26 \\
ROTI & 20,07 & 19,64 & 22,76 & 19,39 & 6,24 & 17,62 \\
SKBM & 28,97 & 28,03 & 11,67 & 6,12 & 0,36 & 15,03 \\
STTP & 16,49 & 15,1 & 18,41 & 14,91 & 12,43 & 15,47 \\
Maksimum & 118,6 & 143,53 & 64,83 & 119,68 & 96,08 & \\
Minimum & 14,71 & 10,52 & 9,42 & 6,12 & 0,36 & \\
Rata-rata & 35,32 & 36,92 & 23,95 & 30,49 & 20,82 & \\
Growth & & 0,47 & 0,52 & 0,47 & 0,43 & \\
\hline Sumbr : & & & & & & \\
\hline
\end{tabular}

Sumber : data diolah, 2018

Tabel 3 menggambarkan bahwa Return On Equity tahun 2013-2017 mempunyai rata-rata setiap tahunnya masing-masing sebesar 35,32\%, 36.92\%, 23,95\%, 30,49\% dan 20,82\% dengan nilai maksimum 143,53\% didapat oleh perusahaan MLBI, sedangkan untuk nilai minimum sebesar 0,36\% didapat oleh SKBM. Dari tahun 2013-2017, tingkat pertumbuhan (growth) mengalami fluktuasi naik-turun.

Tabel 4 : Perhitungan Size

\begin{tabular}{lcccccc}
\hline $\begin{array}{l}\text { Kode Emiten } \\
\text { Perusahaan }\end{array}$ & $\begin{array}{c}\mathbf{2 0 1 3} \\
(\mathbf{\%})\end{array}$ & $\begin{array}{c}\mathbf{2 0 1 4} \\
(\mathbf{\%})\end{array}$ & $\begin{array}{c}\text { Tahun } \\
\mathbf{2 0 1 5}\end{array}$ & $\begin{array}{c}\mathbf{2 0 1 6} \\
\mathbf{( \% )}\end{array}$ & $\begin{array}{c}\mathbf{2 0 1 7} \\
\mathbf{( \% )}\end{array}$ & Rata-rata \\
\hline AISA & 6,7 & 6,86 & 6,95 & 6,96 & 6,98 & 6,89 \\
DLTA & 5,93 & 5,99 & 6,01 & 6,07 & 6,09 & 6,018 \\
ICBP & 7,32 & 7,39 & 7,42 & 7,46 & 7,49 & 7,416 \\
MLBI & 6,25 & 6,34 & 6,32 & 6,35 & 6,39 & 6,33 \\
MYOR & 6,59 & 6,61 & 6,71 & 6,79 & 6,82 & 6,704 \\
ROTI & 6,26 & 6,33 & 6,43 & 6,46 & 6,47 & 6,39 \\
SKBM & 5,69 & 5,81 & 5,88 & 6 & 6,18 & 5,912 \\
STTP & 6,16 & 6,23 & 6,28 & 6,36 & 6,36 & 6,278 \\
Maksimum & 7,32 & 7,39 & 7,42 & 7,46 & 7,49 & \\
Minimum & 5,69 & 5,81 & 5,88 & 6 & 6,09 & \\
Rata-rata & 6,36 & 6,45 & 6,5 & 6,56 & 6,59 & \\
Growth & & 0,30 & 0,30 & 0,30 & 0,30 & \\
\hline Sumber : & & & & & \\
\hline
\end{tabular}

Sumber : data diolah, 2018

Tabel 4 menggambarkan bahwa Size tahun 2013-2017 mempunyai rata-rata setiap tahunnya masing-masing sebesar 6,36\%,6,45\%,6,5\%,6,56\% dan 6,59\% dengan nilai maksimum 7,49\% didapat oleh perusahaan ICBP, sedangkan untuk nilai minimum sebesar 5,69\% didapat oleh SKBM. Dari tahun 2013-2017, tingkat pertumbuhan (growth) cenderung normal. 
Tabel 5. Perhitungan Dividend Payout Ratio

\begin{tabular}{lcccccc}
\hline $\begin{array}{l}\text { Kode Emiten } \\
\text { Perusahaan }\end{array}$ & $\begin{array}{c}\mathbf{2 0 1 3} \\
(\mathbf{\%})\end{array}$ & $\begin{array}{c}\mathbf{2 0 1 4} \\
(\mathbf{\%})\end{array}$ & $\begin{array}{c}\text { Tahun } \\
\mathbf{2 0 1 5}\end{array}$ & $\begin{array}{c}\mathbf{2 0 1 6} \\
\mathbf{( \% )}\end{array}$ & $\begin{array}{c}\mathbf{2 0 1 7} \\
(\mathbf{\%})\end{array}$ & Rata-rata \\
\hline AISA & 8,5 & 0,56 & 0,55 & 0,56 & 0,31 & 2,096 \\
DLTA & 72,66 & 1,02 & 1,01 & 56,8 & 10,05 & 28,308 \\
ICBP & 48,79 & 49,71 & 49,75 & 49,88 & 51,23 & 49,872 \\
MLBI & 100 & 0,68 & 145,92 & 100 & 32,04 & 75,728 \\
MYOR & 19,75 & 0,45 & 21,99 & 34,65 & 0,64 & 15,496 \\
ROTI & 9,99 & 0,63 & 0,59 & 24,82 & 0,51 & 7,308 \\
SKBM & 18,34 & 14,96 & 12,44 & 12,4 & 0,15 & 11,658 \\
STTP & 1,14 & 1,23 & 1,86 & 1,74 & 1,67 & 1,528 \\
Maksimum & 100 & 49,71 & 145,92 & 100 & 51,23 & \\
Minimum & 1,14 & 0,45 & 0,55 & 0,56 & 0,15 & \\
Rata-rata & 34,90 & 8,65 & 29,26 & 35,11 & 12,07 & \\
Growth & & 0,03 & 0,09 & 0,08 & 0,08 & \\
\hline
\end{tabular}

Sumber : data diolah, 2018

Tabel 5 menggambarkan bahwa Dividend Payout Ratio tahun 2013-2017 mempunyai rata-rata setiap tahunnya masing-masing sebesar 39,40\%, 8,65\%, 29,26\%, 35,11\% dan 12,07\% dengan nilai maksimum 145,92\% didapat oleh perusahaan MLBI, sedangkan untuk nilai minimum sebesar 0,15\% didapat oleh SKBM. Dari tahun 2013-2017, tingkat pertumbuhan (growth) mengalami kenaikan pada tahun pertama dan penurunan pada tahun berikutnya.

Tabel 6. Uji Statistik Deskriptif

Descriptive Statistics

\begin{tabular}{lcrrrr} 
& N & Minimum & Maximum & Mean & $\begin{array}{c}\text { Std. } \\
\text { Deviation }\end{array}$ \\
\hline Debt Equity Ratio & 40 & 0,18 & 3,03 & 1,0468 & 0,53953 \\
Current Ratio & 40 & 51,39 & 778,30 & 226,9508 & 169,53195 \\
Return On Equity & 40 & 0,36 & 143,53 & 29,5000 & 32,67127 \\
Size & 40 & 5,69 & 7,49 & 6,4922 & 0,47629 \\
Devidend Payout Ratio & 40 & 0,15 & 145,92 & 23,9993 & 33,61730 \\
Valid N (listwise) & 40 & & & & \\
\hline
\end{tabular}

Sumber : data diolah dengan SPSS 19.00

Berdasarkan hasil pengolahan data pada tabel uji statistik deskriptif diatas diketahui bahwa : 1) Variabel leverage (debt equity ratio) yang merupakan rasio total hutang dengan total ekuitas perusahaan menunjukkan nilai mean sebesar 1,04. Hal ini berarti bahwa rata-rata perusahaan sampel memiliki hutang sebesar 1,04 kali lebih besar dari modal sendiri (ekuitas) yang dimiliki perusahaan. Nilai minimum dari leverage adalah sebesar 0,18 yang berarti bahwa sampel terendah hanya memiliki hutang sebesar $0,18 \mathrm{x}$ dari modal sendiri, sedangkan nilai maksimum leverage (debt equity ratio) sebesar 3,03 berarti bahwa sampel tertinggi memiliki hutang sebesar 3,03x modal sendiri yang dimiliki perusahaan. 2) Variabel likuiditas (Current Ratio) menunjukkan mean sebesar 226,95 yang berarti bahwa rata-rata perusahaan sampel mampu memenuhi kewajiban jangka pendeknya sebesar 226,95 kali dari total aset yang dimiliki perusahaan dalam satu periode. Nilai maksimumnya sebesar 778,30 berarti bahwa sampel tertinggi dapat memenuhi kewajibannya sebesar 778,30 kali dari total asset yang dimiliki perusahaan. Sedangkan nilai minimum 
menunjukkan angka 51,39 yang berarti bahwa sampel terendah dapat memenuhi kewajibannya sebesar 51,m39 kali dari total aset. 3) Hasil dari variabel profitabilitas (Return On Equity) dalam tabel pengujian diatas menunjukkan nilai mean sebesar 29,49 yang berarti bahwa rata-rata perusahaan sampel mampu mendapatkan laba bersih sebesar 29,49\% atau hampir $25 \%$ dari total aset yang dimiliki perusahaan dalam satu periode. Nilai minimum sebesar 0,36 berarti bahwa sampel terendah hanya bisa mendapatkan laba bersih sebesar $36 \%$ dari total aset yang dimiliki perusahaan atau bahkan dapat mengalami kerugian dalam satu periode. Nilai maksimum diketahui sebesar 143,53 yang berarti bahwa sampel tertinggi mendapatkan keuntungan bersih sebesar 144\% dari keseluruhan total aset yang dimiliki perusahaan selama satu periode.

Tabel pengujian statistik deskriptif menunjukkan bahwa variabel size yang merupakan log natural (Ln) dari total aset menunjukkan mean sebesar 6,49. Sedangkan nilai maksimum yang didapat adalah 7,49 dan nilai minimumnya adalah 5,69. Kebijakan dividen (Dividend Payout Ratio) diperoleh mean sebesar 23,99. Hal ini berarti bahwa rata-rata kebijakan pembagian dividen tunai adalah sebesar $23,99 \%$ dari laba per lembar saham yang diperoleh perusahaan. Nilai maksimum sebesar 145,92 menunjukkan bahwa dividen tertinggi dari perusahaan sampel dapat mencapai $145,92 \%$ dari laba per lembar saham yang diperoleh perusahaan, sedangkan nilai minimum kebijakan dividen (Dividend Payout Ratio) adalah 0,15 dari laba per lembar saham yang berarti bahwa dividen terendah dari perusahaan sampel hanya dapat mencapai $0,15 \%$.

Berdasarkan grafik normal probability plot, menunjukkan bahwa data yang dimiliki terlihat merata dan cukup baik. Artinya model regresi tersebut memenuhi asumsi normalitas yang berarti bahwa data terdistribusi secara normal. Hasil dari pengujian multikolonieritas bahwa dari semua variabel memiliki nilai tolerance $>0,10$ (lebih dari 0,10) dan nilai VIF $<10$ (kurang dari 10). Maka tidak terdapat variabel independent yang saling berhubungan dengan variabel independent yang lainnya.

Tabel 8 : Uji Autokorelasi

\begin{tabular}{ccccc}
\hline Durbin-Watson & Du & dl & 4-du & Keterangan \\
\hline 1.775 & 1.786 & 1.230 & 2,214 & Tidak terjadi autokorelasi
\end{tabular}

Sumber : data diolah dengan SPSS 19.00, 2018

Berdasarkan tabel D-W dengan tingkat signifikansi 5\%. Tabel Durbin Watson diketahui nilai dl sebesar 1,230 dan du sebesar 1,786 dimana ketentuannya du < DW < 4-du yang berarti 1,786 < $1,775<2,214$ sehingga dapat disimpulkan bahwa tidak terjadi autokorelasi positif dan negatif antar residual dan asumsi ini terpenuhi.

Dengan grafik scatterplots, titik-titik menyebar secara acak serta tersebar baik diatas maupun dibawah angka 0 pada sumbu $\mathrm{Y}$ dan tidak terdapat suatu pola yang jelas pada penyebaran data tersebut.

Hasil ini dapat disimpulkan bahwa tidak terjadi heterokedastisitas pada model regresi, sehingga model regresi layak digunakan untuk memprediksi kebijakan dividen 
Tabel 9 Uji Adjusted $\mathbf{R}^{2}$

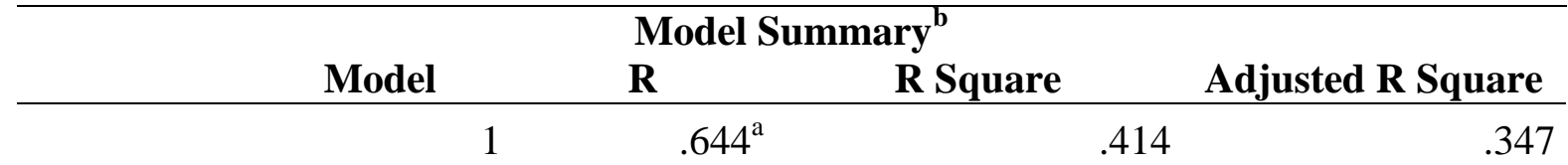

a. Predictors: (Constant), Size, Debt Equity Ratio, Return On Equity, Current Ratio

b. Dependent Variable: Devidend Payout Ratio

Sumber : data diolah dengan SPSS 19.00

Dari tabel diatas, diketahui bahwa nilai adjusted $\mathrm{R}^{2}$ sebesar 0,347. Hal ini berarti bahwa sebesar 34,7\% variabel dependen atau kebijakan dividen (Debt Equity Ratio) dipengaruhi oleh variabel independen yaitu leverage (debt equity ratio), likuiditas (current ratio), profitabilitas (return on equity) dan ukuran perusahaan (size). Sedangkan sisanya yaitu sebesar 65,3\% dijelaskan oleh faktor-faktor lain yang dapat mempengaruhi kebijakan dividen (Debt Equity Ratio).

Tabel 10 Uji Statistik F

\begin{tabular}{|c|c|c|c|c|c|}
\hline \multicolumn{6}{|c|}{ ANOVA $^{b}$} \\
\hline Model & Sum of Squares & Df & Mean Square & $\mathbf{F}$ & Sig. \\
\hline 1 Regression & 18253.321 & 4 & 4563.330 & 6.185 & $.001^{\mathrm{a}}$ \\
\hline Residual & 25821.458 & 35 & 737.756 & & \\
\hline Total & 44074.779 & 39 & & & \\
\hline
\end{tabular}

a. Predictors: (Constant), Size, Debt Equity Ratio, Return On Equity, Current Ratio

b. Dependent Variable: Devidend Payout Ratio

Sumber : data diolah dengan SPSS 19.00

Berdasarkan tabel diatas menunjukkan bahwa nilai Fhitung sebesar 6,185 lebih besar dari nilai Ftabel 3,633 angka signifikansi sebesar 0,001 lebih kecil dari derajat signifikansi 0,05 yang berarti semua variabel independen berpengaruh secara simultan terhadap variabel dependen.

Tabel 11 Uji Statistik t

\section{Coefficients $^{\text {a }}$}

\begin{tabular}{|c|c|c|c|c|c|c|c|c|}
\hline \multirow{2}{*}{\multicolumn{2}{|c|}{ Model }} & \multicolumn{2}{|c|}{$\begin{array}{l}\text { Unstandardized } \\
\text { Coefficients }\end{array}$} & \multirow{2}{*}{$\begin{array}{c}\text { Standardized } \\
\text { Coefficients } \\
\text { Beta }\end{array}$} & \multirow[t]{2}{*}{ t } & \multirow{2}{*}{ Sig. } & \multicolumn{2}{|c|}{$\begin{array}{c}\text { Collinearity } \\
\text { Statistics }\end{array}$} \\
\hline & & B & $\begin{array}{c}\text { Std. } \\
\text { Error }\end{array}$ & & & & Tolerance & VIF \\
\hline \multirow[t]{7}{*}{1} & (Constant) & 33.629 & 69.806 & & -.482 & .633 & & \\
\hline & Debt Equity Ratio & - & 12.829 & -.541 & - & .013 & .395 & 2.53 \\
\hline & & 33.728 & & & 2.629 & & & 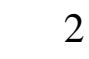 \\
\hline & Current Ratio & -.043 & .037 & -.215 & - & .256 & .482 & 2.07 \\
\hline & & & & & 1.155 & & & 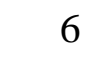 \\
\hline & Return On Equity & .766 & .157 & .745 & 4.868 & .000 & .716 & 1.39 \\
\hline & Size & 12.326 & 9.596 & .175 & 1.285 & .207 & .906 & 1.10 \\
\hline
\end{tabular}

a. Dependent Variable: Devidend Payout Ratio

Sumber : data diolah dengan SPSS 19.00, 2018 
Dari hasil perhitungan table diatas menunjukkan bahwa DER, CR dan Size mempunyai nilai signifikan lebih besar dari derajat signifikansi 0,05 yang menunjukkan bahwa tidak ada pengaruh signifikan terhadap DPR. Sedangkan ROE mempunyai nilai signifikansi kurang dari derajat signifikan 0.05 yang menunjukkan terdapat pengaruh signifikan terhadap DPR.

Pengaruh Leverage $\left(\mathrm{X}_{1}\right)$ terhadap Dividend Payout Ratio (Y). Pada hasil penelitian ini Debt Equity Ratio tidak terdapat pengaruh signifikan terhadap Dividend Payout Ratio. Apabila semakin tinggi tingkat leverage, maka semakin besar pula resiko yang dihadapi perusahaan dan semakin besar return yang diharapkan. Dividend Payout Ratio yang tinggi menunjukkan tingkat leverage yang tinggi sehingga tingkat hutang dan beban bunga juga semakin tinggi. Perusahaan akan lebih memfokuskan untuk membayar hutang tersebut dan menjadikan labanya untuk ditahan sehingga dividen yang dibagikan kecil jumlahnya.

Pengaruh Current Ratio $\left(\mathrm{X}_{2}\right)$ terhadap Dividend Payout Ratio (Y). Pada hasil penelitian ini mengatakan bahwa Current Ratio tidak berpenngaruh signifikan terhadap Dividend Payout Ratio karena perusahaan lebih memfokuskan untuk memenuhi kewajiban jangka pendeknya dibandingkan dengan membagikan dividennya. Dalam hal ini, perusahaan juga menggunakan labanya untuk biaya operasional perusahaan sendiri, sehingga laba tidak dibagikan dalam bentuk dividen. Hal ini ditunjukkan dengan tingkat pertumbuhan Current Ratio setiap tahunnya yang semakin meningkat ditandai dengan meningkatnya kas yang mempengaruhi jumlah aktiva atau asset lancar.

Pengaruh Return On Equity $\left(\mathrm{X}_{3}\right)$ terhadap Dividend Payout Ratio (Y). Hasil penelitian ini mengatakan bahwa Return On Equity berpengaruh signifikan positif terhadap Dividend Payout Ratio. Dimana ketika Return On Equity yang tinggi mencerminkan bahwa profitabilitas perusahaan dalam keadaan baik, dapat pula dikatakan bahwa kondisi kinerja perusahaan baik. Besarnya Return On Equity juga merupakan dasar sebagai pertimbangan pemilik perusahaan untuk menentukan besarnya laba yang diperoleh dan nantinya akan dibagikan dalam bentuk dividen. Semakin tinggi laba yang diperoleh perusahaan, maka semakin tinggi pula dividen yang dibagikan.

Pengaruh Size $\left(\mathrm{X}_{4}\right)$ terhadap Dividend Payout Ratio $(\mathrm{Y})$. Hasil dari penelitian ini menyatakan bahwa Size tidak berpengaruh signifikan terhadap Dividend Payout Ratio. Karena semakin besar ukuran suatu perusahaan, semakin besar goncangan global yang dirasakan perusahaan dan semakin berat beban yang ditanggung oleh perusahaan. Hal tersebut membuat perusahaan akan mengurangi proporsi dividen yang dibagikan kepada pemegang saham.

Pengaruh Debt Equity Ratio $\left(\mathrm{X}_{1}\right)$, Current Ratio $\left(\mathrm{X}_{2}\right)$, Return On Equity $\left(\mathrm{X}_{3}\right)$ dan Size $\left(\mathrm{X}_{4}\right)$ Terhadap Dividend Payout Ratio (Y). Hasil penelitian ini menyatakan bahwa Debt to Equity Ratio, Current Ratio, Return On Equity dan Size secara simultan berpengaruh positif dan signifikan terhadap Dividend Payout Ratio yang terbukti dengan nilai signifikansi 0,001 >0,05. Mengacu pada Dividend Signalling Theory bahwa kinerja perusahaan yang ditunjukkan dengan tingkat leverage, likuiditas, profitabilitas dan ukuran perusahaan dapat dijadikan sebagai acuan untuk memberikan gambaran tentang expected return dari investasi saham dapat diperoleh pemegang saham. Oleh karena itu variabel leverage, likuiditas, profitabilitas dan ukuran perusahaan secara bersama-sama bisa menjelaskan bahwa terdapat pengaruh dalam menentukan besar kecilnya jumlah dividen yang dibagikan kepada para pemegang saham.

Pengaruh Variabel Dominan Terhadap Dividend Payout Ratio (Y). Diantara empat variabel (Leverage, Likuiditas, Profitabilitas dan Ukuran Perusahaan) yang paling dominan berpengaruh terhadap Kebijakan Dividen adalah variabel profitabilitas. Karena semakin besar keuntungan yang diperoleh perusahaan, maka akan memberikan dividen yang besar pula terhadap para pemegang 
saham. Selain itu juga, dividen yang diberikan atas keuntungan yang diperoleh perusahaan bisa menjadi bahan pertimbangan untuk mengelola investasi saat ini.

\section{KESIMPULAN}

Variabel leverage, likuiditas, profitabilitas dan ukuran perusahaan berpengaruh signifikan secara simultan atau bersama-sama terhadap kebijakan dividen karena nilai signifikansi uji $\mathrm{F}$ lebih kecil dari derajat signifikansi 0,05 . Variabel leverage tidak berpengaruh secara parsial terhadap variabel kebijakan dividen dinyatakan dengan nilai signifikansi lebih besar dari derajat signifikansi 0,05. Variabel likuiditas tidak berpengaruh secara parsial terhadap variabel kebijakan dividen dinyatakan dengan nilai signifikansi lebih besar dari derajat signifikansi 0,05. Variabel profitabilitas berpengaruh secara parsial terhadap variabel kebijakan dividen dinyatakan dengan nilai signifikansi lebih kecil dari derajat signifikansi 0,05 . Variabel ukuran perusahaan tidak berpengaruh secara parsial terhadap variabel kebijakan dividen dinyatakan dengan nilai signifikansi lebih besar dari derajat signifikansi 0,05. Diantara keempat variabel leverage, likuiditas, profitabilitas dan ukuran perusahaan yang termasuk variabel dominan adalah profitabilitas. Karena memiliki nilai standar koefisien yang lebih tinggi dibanding dengan variabel yang lain.

\section{DAFTAR PUSTAKA}

Abdullah, S. (1993). Pengaruh dari kepemilikan Manajerial, Kebijakan Hutang, Laba dan Pertumbuhan perusahaan Terhadap Divident Payout Ratio. Jurnal Riset Akuntansi. Indonesia.

Ahmad, H. M. (2009). Manajemen Keuangan. Yogyakarta : BPFE

Arilaha, C. S. (2009). Analisis Faktor-faktor yang Berpengaruh Terhadap Dividend Payout Ratio. Universitas Diponegoro. Semarang

Dewi, S. C. (2008). Pengaruh Kepemilikan Managerial, Kepemilikan Institusional, Kebijakan Hutang, Profitabilitas dan Ukuran Perusahaan terhadap Kebijakan Dividen. Jurnal Bisnis dan Akuntansi. 10(1):47-58

Eltya, S. \& Azizah, D. F. (2016). Pengaruh Leverage, Likuiditas, Profitabilitas Dan Ukuran Perusahaan Terhadap Kebijakan Dividen (Studi Pada Perusahaan Perbankan Yang Terdaftar Di Bursa Efek Indonesia Periode 2012-2014). Jurnal Administrasi Bisnis. 38(2):55-62.

Ghozali. I. (2012). Aplikasi Analisa Multivariate Dengan Program IBM SPSS 21 Update PLS Regresi. Edisi 7. Semarang. Universitas Diponegoro.

Harahap, S. S. (2011). Analisis Kritis atas Laporan Keuangan. Jakarta : Salemba Empat

Indriantoro, N dan Supomo, B. (2002). Metodologi Penelitian Bisnis. Yogyakarta : BPFE.

Lestari, F. Tanuatmodjo, H. dan Mayasari. (2016). Pengaruh Likuiditas Dan Profitabilitas Terhadap Kebijakan Dividen. Journal of Business Management Education. 1(2):11-16.

Lopolusi, I. (2013). Analisis Faktor-Faktor yang Mempengaruhi Kebijakan Dividen Sektor Manufaktur yang Terdaftar di PT Bursa Efek Indonesia Periode 2007-2011. Calyptra :Jurnal Ilmiah Mahasiswa Universitas Surabaya. 2(1): 1-18.

Nensia, S. (2017). Pengaruh Electronic Word of Mouth di Media Sosial Terhadap Brand Image Coffee Shop (Studi pada Followers Account Instagram @Dw_Coffee di Kota Malang). Diss. Universitas Muhammadiyah Malang.

Parica, R., \& Ekasiwi, H. R. (2013). Pengaruh Laba Bersih, Arus Kas Operasi, Likuiditas, dan Profitabilitas terhadap Kebijakan Dividen Pada Perusahaan Automotive and Allied Product yang terdaftar di BEI. Jurnal Akuntansi Universitas Riau. 2:1-15.

Pasadena, R. P. (2013). Pengaruh Likuiditas, Leverage, Profitabilitas dan Ukuran Perusahaan Terhadap Kebijakan Dividen pada Perusahaan Manufaktur yang Terdaftar di Bursa Efek 
Indonesia. Skripsi. Program Studi Akuntansi Fakultas Ekonomi dan Bisnis Universitas Syarif Hidayatullah Jakarta.

Purnama, N. R. A dan Sri, S. (2017). Analisis pengaruh profitabilitas dan Likuiditas Terhadap Kebijakan DIviden Kas (Studi pada Perusahaan Otomotif dan Komponennya yang Listing di Bursa Efek Indonesia Periode 2006-2016). Jurnal Administrasi Bisnis. 51(2): 201-206

Puspita, F. (2009). Analisis factor-faktor yang Mempengaruhi kebijakan Dividen pada Perusahaan yang terdaftar di Bursa Efek Jakarta periode 2005-2007. Tesis Manajemen Pasca Sarjana UNDIP. Semarang. http://eprints.undip.ac.id/17411/. Diakses tanggal 29 Juli 2018. Hal 1.

Putri, A. A. (2015). Pengaruh Profitabilitas, Leverage, Collateralizable Assets dan Investment Opportunity Set Terhadap Kebijakan DIviden (Studi Empiris : Bursa Efek Indonesia 20102013). Jurnal Ilmiah. 3: 02

Rahayuningtyas, S. (2014). Pengaruh Rasio-Rasio Keuangan Terhadap Dividend Payout Ratio (DPR) (Studi Pada Perusahaan yang Listing Di BEI Tahun 2009 - 2011). Jurnal Administrasi Bisnis. 7(2)

Rahmi, S. F. (2005). Analisis Faktor-faktor yang Mempengaruhi Dividend Payout Rasio pada Perusahaan Manufaktur di Bursa Efek Jakarta. Skripsi mahasiswa Universitas Riau, Pekanbaru.

Riyanto, B. (2008). Dasar-Dasar Pembelajaran Perusahaan. Yogyakarta: BPFE

Sugiyono. (2009). Metode Penelitian Bisnis. Bandung: Alfabeta.

Taroreh, R., \& Thaib, C. (2015). Pengaruh Kebijakan Hutang dan Profitabilitas terhadap Kebijakan Dividen (Studi pada Perusahaan Foods And Beverages yang Terdaftar di BEI Tahun 20102014). Jurnal Riset Ekonomi, Manajemen, Bisnis dan Akuntansi. 3(4).

Yudiana, I. G. Y., \& Yadnyana, I. K. (2016). Pengaruh Kepemilikan Manajerial, Leverage, Investment Opportunity Set Dan Profitabilitas Pada Kebijakan Dividen Perusahaan Manufaktur. E-Jurnal Akuntansi.111-141.

http://www.idx.co.id Visitasi 27 Juli 2018 